\title{
Glycolysis and gluconeogenesis in the liver of catfish fed with different concentrations of proteins, lipids and carbohydrates
}

\author{
[Glicólise e gliconeogênese no fígado de jundiá alimentado com diferentes concentrações \\ de proteínas, lipídeos e carboidratos] \\ J.F.B. Melo ${ }^{1}$, L. M, Lundstedt ${ }^{2}$, L.A.K. Inoue ${ }^{3}$, I. Metón ${ }^{4}$, I.V. Baanante ${ }^{4}$, G. Moraes ${ }^{5}$ \\ ${ }^{1}$ Universidade Federal do Vale do São Francisco - UNIVASF - Petrolina, PE \\ ${ }^{2}$ Embrapa Pesca e Aquicultura - Palmas, TO \\ ${ }^{3}$ Embrapa Amazônia Ocidental - Manaus, AM \\ ${ }^{4}$ Universidad de Barcelona - Barcelona, Espanha \\ ${ }^{5}$ Universidade Federal de São Carlos - UFSCar - São Carlos, SP
}

\begin{abstract}
The activities of enzymes from a number of metabolic pathways have been used as a tool to evaluate the best use of nutrients on fish performance. In the present study the catfish Rhamdia quelen was fed with diets containing crude protein-lipid-carbohydrate (\%) as follows: treatment (T) T1: 19-19-44; T2: 26-1539; T3: 33-12-33; and T4: 40-10-24. The fish were held in tanks of re-circulated, filtered water with controlled temperature and aeration in $2000 \mathrm{~L}$ experimental units. The feeding experiment lasted 30 days. The following enzymes of the carbohydrate metabolism were determined: Glucokinase (GK), Phosphofructokinase 1 (PFK-1), Pyruvate kinase (PK), Fructose-1,6-biphosphatase 1 (FBP-1). The activities of 6 phosphogluconate dehydrogenase (6PGDH) and glucose 6 phosphate dehydrogenase (G6PDH) were also assayed. The influence of nutrient levels on the enzyme activities is reported. The increase of dietary protein plus reduction of carbohydrates and lipids attenuates the glycolytic activity and induces hepatic gluconeogenesis as a strategy to provide metabolic energy from amino acids. The fish performance was affected by the concentrations of protein, lipid and carbohydrates in the diet. The greatest weight gain was obtained in fish fed diet T4 containing $40.14 \%$ of crude protein, $9.70 \%$ of lipids, and $24.37 \%$ of carbohydrate, respectively.
\end{abstract}

Keywords: metabolism, enzymes, nutrition, adaptation

\section{RESUMO}

As atividades de enzimas das vias metabólicas têm sido utilizadas como uma ferramenta para avaliar a melhor utilização dos nutrientes e o desempenho dos peixes. No presente estudo, o jundiá foi alimentado com rações contendo diferentes concentrações de proteína bruta, lipídeos e carboidratos (\%), da seguinte forma: tratamento (T) T1: 19-19-44; T2: 26-15-39; T3: 33-12-33; e T4: 40-10-24. Os peixes foram mantidos em tanques de recirculação, com água filtrada, temperatura controlada e aeração em unidades experimentais de 2.000L. O período experimental foi de 30 dias. Foram aferidas as atividades das enzimas glicoquinase (GK), fosfofrutoquinase 1 (PFK-1), piruvato quinase (PK) e frutose-1,6difosfatase (FBP-1). Também foram aferidas as atividades da 6-fosfogluconato desidrogenase (6PGDH) e glicose-6-fosfato desidrogenase (G6PDH) da via das pentoses. É relatado que níveis de nutrientes influenciam as atividades enzimáticas das vias metabólicas. No presente estudo, o aumento da proteína da dieta e a redução de hidratos de carbono e lipídeos reduziram a atividade glicolítica e induziram a gliconeogênese hepática como uma estratégia para fornecer energia pelos aminoácidos. O desempenho dos peixes foi afetado pelas concentrações de proteínas, lipídeos e carboidratos na dieta. O maior ganho de peso foi obtido em peixes alimentados com dieta T4 contendo 40,14\% de proteína bruta, 9,70\% de lipídeos, e 24,37\% de carboidratos, respectivamente.

Palavras-chave: metabolismo, enzimas, nutrição, adaptação

Recebido em 2 de abril de 2015

Aceito em 29 de março de 2016

E-mail: melojfb@yahoo.com.br 


\section{INTRODUCTION}

Among the macronutrients, proteins play a pivotal role in many biological functions. In particular, fish present meaningful dietary protein requirements. Lipids are assumed as the main source of metabolical energy; however, tropical fresh water species are usually able to use great deals of carbohydrate while most fish burn proteins as ordinary fuel. These facts deserve special attention when a diet is designed for an intensive fish rearing system. Nutritional requirements must look upon many aspects such as: fish species, metabolic demands, growth phase and potential to adapt to environmental changes. In essence, adaptation to external changes is related to two factors, gene assembly and the array of expressed enzymes; and both are directly related to metabolism.

To date, the number of studies on metabolism of fish related to nutritional status is scarce. However, many studies have focused on the comprehension of the metabolic phenomena toward the improvement of nutrient utilization and the fish performance in aquaculture systems. Among carnivorous animals, fishes require higher levels of dietary protein, ordering amino acids toward protein synthesis and glucose formation for energetic requirements (SánchezMuros et al., 1998). Increases of plasma amino acids after high protein feeding or aestivation make up the large source of energy for carnivorous fish. Studies on regulatory aspects of gluconeogenesis in Oncorhyncus mykiss fed high protein levels report the rise of plasma amino acids (Cowey et al., 1977). Partial replacement of protein by dietary carbohydrates is well tolerated in Sparus aurata (Metón et al., 2003). The omnivorous Rhamdia hilari also adapts its metabolism to high levels of dietary carbohydrates, using dietary lipid and protein as the main source of energy in the muscle during starvation. Moreover, lipid and protein synthesis in muscle and liver are remarkably higher after refeeding or insulin administration (Machado et al., 1988).

This is a consequence of the use of carbohydrate for energetic processes sparing amino acids for muscle protein synthesis. Therefore, the possibility of feeding fish with different contents of carbohydrates to improve the use of nutrients is a promising item, particularly in omnivorous species.

The South American catfish "jundiá” Rhamdia quelen displays several farming qualities. Eleven species are presently included in the Rhamdia genus, a Neotropical Siluriform-Pimelodidae reported from Mexico to Argentina (Silfvergrip, 1996.). The $R$. quelen accepts artificial feeding since hatching, presenting good survival rates and fast growth and development. Nowadays, there is little information concerning metabolism of species from the genus Rhamdia. Recently, we have reported that the levels of dietary protein affect the protein metabolism and nitrogen excretion in juveniles of that species (Melo et al., 2006), and hypothesized that the metabolic machinery is adapted to changes in diet composition. We have been proposing the study of metabolic changes combined with digestive profiles as a tool to infer the fish performance and evaluate its effort to cope with different nutritional circumstances (Lundstedt, et al., 2004). In the present study, adaptive adjustments of metabolic enzymes in $R$. quelen fed distinct contents of nutrients were investigated. The changes observed in the metabolic frames of $R$. quelen were used in attempt to match the levels of dietary macronutrients with the best growth performance.

\section{MATERIALS AND METHODS}

The present study was approved by the bioethics committee of the University of Barcelona-ES, under number 349002-ES/2003. One-hundredand-sixty juvenile jundiá $R$. quelen from the same strain $(44.98 \pm 13.32 \mathrm{~g}$ and $16.92 \pm 1.44 \mathrm{~cm})$ were equally distributed in four $2000 \mathrm{~L}$ tanks in a close, re-circulated water system and acclimated for one week and fed commercial pellets. Afterwards, feeding was discontinued and the fish were fed to satiety for 30 days twice a day with the experimental diets. The water quality was monitored and kept at: temperature $25 \pm 1^{\circ} \mathrm{C}$, $\mathrm{pH} 7.2$, dissolved oxygen $5.4 \mathrm{mgL}^{-1}$, alkalinity $42 \mathrm{mgL}^{-1}$ and ammonia $0.12 \mathrm{mgL}^{-1}$. No fish mortality was observed during the experiment.

The experimental feeding consisted of four diets containing: $19,26,33$, and $40 \%$ of crude protein (CP); 19, 15, 12, and $10 \%$ of lipids, and 44, 39, 33 , and $24 \%$ of carbohydrate, respectively (Table 1). We conducted a control treatment, 
where the animals were fasted during the experimental period. Dietary average gross energy was $4490 \mathrm{Kcal} \mathrm{Kg}^{-1}$. Nutrient composition was previously determined and the diet ingredients were analyzed according to the Association of Official Analytical Chemists. After the trial period, the feeding was discontinued for $24 \mathrm{~h}$ and 10 fish per treatment were randomly netted, anaesthetized with benzocaine $\left(100 \mathrm{mgL}^{-1}\right.$ water), and killed by cervical pinch. The fish were dissected and liver were collected and immediately frozen into liquid nitrogen. All samples were preserved at $80^{\circ} \mathrm{C}$ until analyses.

Table 1. Composition of the experimental diets

\begin{tabular}{|c|c|c|c|c|}
\hline & \multicolumn{4}{|c|}{ Experimental treatments ${ }^{1}$} \\
\hline & $\begin{array}{c}\mathrm{T} 1 \\
(19-19-44)\end{array}$ & $\begin{array}{c}\mathrm{T} 2 \\
(26-15-39)\end{array}$ & $\begin{array}{c}\text { T3 } \\
(33-12-33)\end{array}$ & $\begin{array}{c}\mathrm{T} 4 \\
(40-10-24)\end{array}$ \\
\hline \multicolumn{5}{|l|}{ Formulation (\%) } \\
\hline Fish meal & 14.2 & 24.2 & 19.2 & 35.2 \\
\hline Soy bran & 8.0 & 11.0 & 11.0 & 24.0 \\
\hline Yeast & 8.0 & 8.0 & 20.0 & 15.0 \\
\hline Corn & 38.0 & 30.0 & 26.0 & 8.0 \\
\hline Wheat & 14.0 & 14.0 & 14.0 & 10.0 \\
\hline Vegetal Oil & 17.0 & 12.0 & 9.0 & 7.0 \\
\hline Salt & 0.5 & 0.5 & 0.5 & 0.5 \\
\hline Vitamin mixture ${ }^{2}$ & 0.2 & 0.2 & 0.2 & 0.2 \\
\hline Mineral mixture ${ }^{3}$ & 0.1 & 0.1 & 0.1 & 0.1 \\
\hline Vitamin C & 0.05 & 0.05 & 0.05 & 0.05 \\
\hline \multicolumn{5}{|l|}{ Chemical Analysis } \\
\hline Crude protein $(\%)$ & 19.37 & 26.33 & 33.2 & 40.14 \\
\hline Gross Energy (kcal/kg) & 4.419 & 4.610 & 4.504 & 4.438 \\
\hline Fat $(\%)$ & 18.57 & 14.76 & 11.98 & 9.70 \\
\hline Crude Fiber $(\%)$ & 3.24 & 3.24 & 3.14 & 3.92 \\
\hline Ash (\%) & 5.35 & 7.88 & 7.53 & 12.61 \\
\hline Dry matter $(\%)$ & 90.06 & 89.81 & 89.61 & 90.74 \\
\hline Carbohydrate $(\%)^{4}$ & 43.53 & 38.60 & 32.5 & 24.37 \\
\hline
\end{tabular}

${ }^{\mathrm{T}}$ Experimental treatments (dietary protein-lipid-carbohydrate content, respectively);

${ }^{2}$ Composition of vitamin mixture/Kg diet: Vitamin A 10.000 UI, E 50mg, D 2000 UI, K-3 25mg, B-12 50mg, Thiamin 15mg, Riboflavin 35mg, Pyridoxine 10mg, Biotin 250mg, Folic acid 5mg, Pantothenic Acid 60mg, Niacin $60 \mathrm{mg}$, Choline $120 \mathrm{~g}$. Antioxidant $50 \mathrm{~g}$.

${ }^{3}$ Composition of the mineral mixture/Kg of diet: Iron $40 \mathrm{mg}$, Copper $12,5 \mathrm{mg}$, Zinc $30 \mathrm{mg}$, Cobalt $1 \mathrm{mg}$, Iodine $1,4 \mathrm{mg}$ and Selenium 0,2mg.

${ }^{4}$ Carbohydrate $(\%)=$ Dry matter $-($ Crude protein + fat + ash + crude fiber $)$

Liver samples were powdered under liquid nitrogen, homogenized in $50 \mathrm{mM}$ Tris- $\mathrm{HCl} \mathrm{pH}$ $7.5, \quad 4 \mathrm{mM}$ EDTA, $50 \mathrm{mM} \quad \mathrm{NaF}, \quad 0.5 \mathrm{mM}$ phenylmethylsulfonyl fluoride, $1 \mathrm{mM}$ 1,4dithiothreitol and $250 \mathrm{mM}$ sucrose with a PTA-7 Polytron (Kinematica GmbH, Littau-Luzern, Switzerland) position 3 for $30 \mathrm{sec}$, and centrifuged at $20000 \mathrm{x}$ g for $30 \mathrm{~min}$ at $4^{\circ} \mathrm{C}$. Supernatants were used as crude enzyme source.

Glucokinase (GK), phosphofructokinase 1 (PFK1), pyruvate kinase (PK), fructose-1,6bisphosphatase 1 (FBP-1), 6 phosphogluconate dehydrogenase (6-PGDH) and glucose 6 phosphate dehydrogenase (G6PDH) were assayed in a COBAS MIRAS spectrophotometric analyzer (Roche, Basel, Switzerland). Enzyme assays were carried out at $30^{\circ} \mathrm{C}$ and followed at 340nm.

GK reaction mixture was: $0.2 \mathrm{~mL}$ of $100 \mathrm{mM}$ Tris- $\mathrm{HCl} \mathrm{pH} 7.75,7.5 \mathrm{mM} \mathrm{MgCl}_{2}, 100 \mathrm{mM} \mathrm{KCl}$, $2.5 \mathrm{mM}$ DTT, $1 \mathrm{mM}$ NADP, $1 \mathrm{mU} \cdot \mathrm{mL}^{-1}$ yeast glucose-6-phosphate dehydrogenase and 5U/L of crude enzyme source previously filtered in Sephadex G-25. Enzyme reaction was started by $6 \mathrm{mM}$ ATP and $100 \mathrm{mM}$ or $0.5 \mathrm{mM}$ glucose. Enzyme activity was calculated from the rate of 
NADPH formation at $340 \mathrm{~nm}$ for $100 \mathrm{mM}$ glucose minus the rate for $0.5 \mathrm{mM}$ glucose (hexokinase activity), after correcting the interferences from glucose dehydrogenase (Tranulis et al. 1996).

PFK-1 reaction mixture was: $0.2 \mathrm{~mL}$ of $100 \mathrm{mM}$ Tris- $\mathrm{HCl} \mathrm{pH} 8.25,5 \mathrm{mM} \mathrm{MgCl}_{2}, 50 \mathrm{mM} \mathrm{KCl}$, $0.15 \mathrm{mM}$ ammonium sulfate, $4 \mathrm{mM} 2-$ mercaptoethanol, $10 \mathrm{mM}$ fructose 6-phosphate, $30 \mathrm{mM}$ glucose 6-phosphate, $0.675 \mathrm{UI} \mathrm{mL}^{-}$ ${ }^{1}$ aldolase, 5UI mL ${ }^{-1}$ triose phosphate isomerase, $2 \mathrm{UI} \mathrm{mL}^{-1}$ glycerol 3-phosphate dehydrogenase, (NADH $0,15 \mathrm{mM}$ ) and $4 \mu \mathrm{L}$ of crude enzyme source. Enzyme reaction was started by the addition of $1 \mathrm{mM}$ ATP and calculated from the rate of NAD formation at 340nm (Castaño et al., 1979).

PK reaction mixture was: $0.25 \mathrm{~mL}$ of $70 \mathrm{mM}$ glycyl-glycine $\mathrm{pH} 7.4,10 \mathrm{mM} \mathrm{MgCl}_{2}$, $100 \mathrm{mM} \quad \mathrm{KCl}, \quad 0.15 \mathrm{mM} \quad \mathrm{NADH}, \quad 2.8 \mathrm{mM}$ phosphoenolpyruvate, $21 \mathrm{UI} \mathrm{mL}^{-1}$ lactate dehydrogenase and $2.5 \mu \mathrm{L}$ of crude enzyme source. Enzyme reaction was started by the addition of $2.5 \mathrm{mM}$ ADP and calculated from the rate of NAD formation at $340 \mathrm{~nm}$ (Staal et al., 1975).

FBP-1 reaction mixture was: $0.2 \mathrm{~mL}$ of $85 \mathrm{mM}$ imidazole- $\mathrm{HCl} \mathrm{pH} 7.7,5 \mathrm{mM} \mathrm{MgCl}_{2}, 0.5 \mathrm{mM}$ NADP, $\quad 12 \mathrm{mM}$ 2-mercaptoethanol, $0.05 \mathrm{mM}$ fructose 1,6-bisphosphate, $2.5 \mathrm{UI} \mathrm{mL} \mathrm{m}^{-1}$ glucose-6-

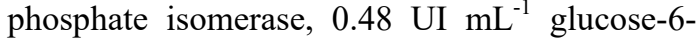
phosphate dehydrogenase and $4 \mu \mathrm{L}$ of crude enzyme source. Enzyme reaction was started by the enzyme addition and calculated from the rate of NADPH formation at 340nm (Bartrons et al., 1983).

6-PGDH reaction mixture was: $83 \mathrm{mM}$ imidazole-HCl buffer at $\mathrm{pH} 7.7,3 \mathrm{mM} \mathrm{MgCl}_{2}$, $0.5 \mathrm{mM}$ NADP and 2mM 6-P gluconate. Enzyme reaction was triggered by the addition of the crude enzyme extract and followed by the NADPH formation at 340nm (Bergmeyer, 1984).

G6PDH reaction mixture was: $78 \mathrm{mM}$ imidazole$\mathrm{HCl}$ buffer at $\mathrm{pH} 7.7,5 \mathrm{mM} \mathrm{MgCl}_{2}, 1 \mathrm{mM}$ NADP and $1 \mathrm{mM}$ glucose 6-P. Enzyme reaction was triggered by the addition of the crude enzyme extract and followed by the NADPH formation at 340nm (Metón, 1996).

One enzyme unit (UI) was defined as the enzyme amount needed to catalyze one mole of substrate per min. The enzyme specific activity was calculated based on the protein concentration of every sample of crude enzyme extract, which was performed according to the method of using bovine serum albumin as standard.

The experimental design was established as randomized incomplete blocks-RIB formed by four blocks and ten fish per block, where each fish was assigned as an experimental unit. The data were submitted to ANOVA and differences among treatment means were checked by the Turkey post-test Tukey for $\mathrm{P}<0.05$.

\section{RESULTS}

Different amounts of dietary protein, lipids and carbohydrates brought about responses on the activity of glycolytic and gluconeogenic enzymes (Fig. 1). The activity of the glycolytic enzymes GK, PK and PFK-1 lessened in fish fed with diets with decreasing carbohydrate contents (Figure 2). The activity of the gluconeogenic enzyme FBP-1 displayed an opposite profile. Such activity increased in fish fed with rising amounts of protein (Figure 2).

The fish performance was affected by dietary protein, carbohydrate and lipid (Table 2). The greatest weight gain was obtained in fish fed $\mathrm{T} 4$ diet with $40.14 \%$ crude protein, $9.70 \%$ of lipids and $24.37 \%$ carbohydrate. The fish kept starved over the trial showed reduction in weight gain.

Activities of 6-PGDH and G6PDH were not affected by dietary contents of protein and carbohydrates (Table 2). The levels of these nutrients gave rise to reduction in the activity of these enzymes in the fish that remained fasted. 
Glycolysis and gluconeogenesis...
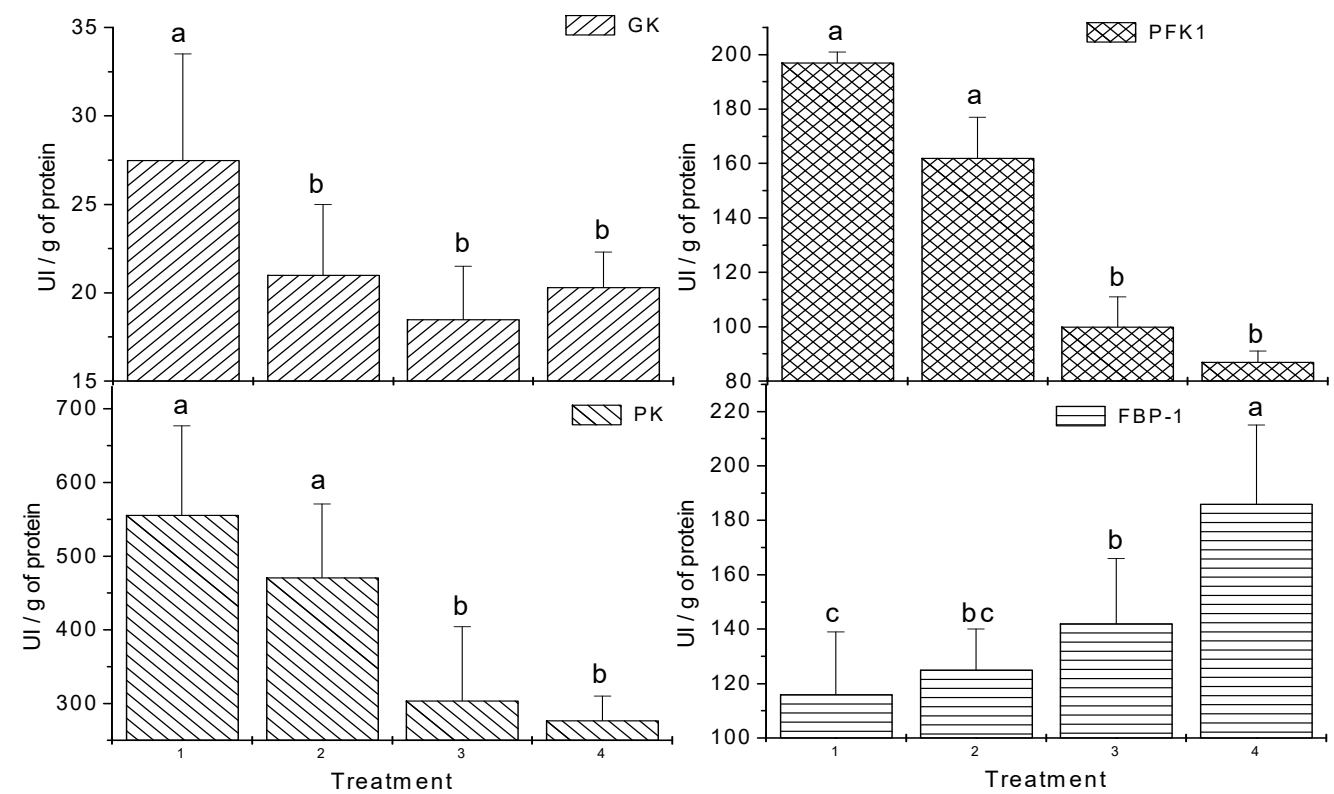

Figure 1. Glucokinase (GK), phosphofructokinase 1 (PFK-1), pyruvate kinase (PK) and fructose-1,6bisphosphatase 1 (FBP-1) activities in the liver of $R$. quelen fed with diferent contents of macronutrients. The enzyme activities are expressed in UI/g of protein as mean $\pm \mathrm{SD}(\mathrm{n}=10)$; significant differences $(\mathrm{P}<0.05)$ are presented as distinct letters. T1 (19-19-44), T2 (26-15-39), T3 (33-12-33), T4 (40-10-24) (crude protein-lipid-carbohydrate, \%).
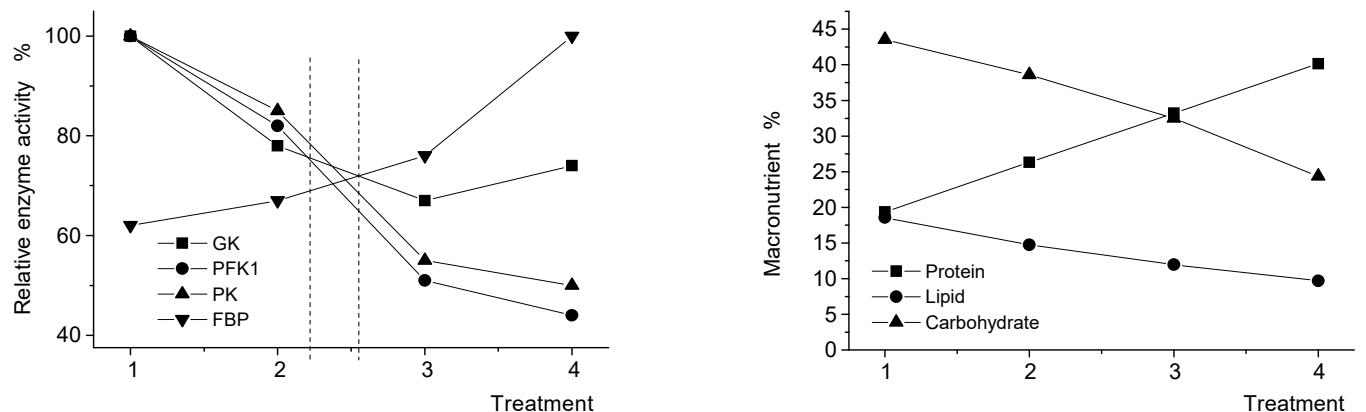

(a)

Figure 2. (a) Relative activities (\%) of the glycolytic and gluneocogenic enzymes: glucokinase (GK), phosphofructokinase 1 (PFK-1), pyruvate kinase (PK) and fructose-1,6-bisphosphatase 1 (FBP-1). (b) Content $(\%)$ of dietary macronutrients (protein, lipid and carbohydrate) in the four treatments are allowed by interpolating their values.

Table 2. Enzymatic activity of G6PDH, 6-PGDH (mU/mg protein) in liver of Rhamdia quelen and weight gain fed different protein-lipid-carbohydrate contents and fasting

\begin{tabular}{lccc} 
Treatments $^{1}$ & G6PDH & 6PGDH & Weight gain $(\mathrm{g})$ \\
\hline Fasted & $140.97 \mathrm{~b} \pm 11.85$ & $31.57 \mathrm{~b} \pm 7.61$ & $32.53 \mathrm{~d} \pm 5.32$ \\
T1 $(19-19-44)$ & $191.59 \mathrm{a} \pm 33.64$ & $48.55 \mathrm{a} \pm 11.35$ & $63.40 \mathrm{c} \pm 4.56$ \\
T2 $(26-15-39)$ & $265.89 \mathrm{a} \pm 66.89$ & $52.42 \mathrm{a} \pm 6.99$ & $73.28 \mathrm{~b} \pm 5.12$ \\
T3 $(33-12-33)$ & $268.97 \mathrm{a} \pm 79.95$ & $47.16 \mathrm{a} \pm 17.93$ & $77.72 \mathrm{~b} \pm 6.48$ \\
T4 $(40-10-24)$ & $233.48 \mathrm{a} \pm 68.93$ & $51.65 \mathrm{a} \pm 14.40$ & $97.72 \mathrm{a} \pm 5.09$ \\
\hline
\end{tabular}

${ }^{\mathrm{I}}$ Protein-lipid-carbohydrate levels (\%) 


\section{DISCUSSION}

It is widely known that fishes are remarkable protein consumers. This macronutrient, pivotal for the most vital functions, takes place as provider of radicals and or building blocks of several biomolecules. However, the surplus of protein works as an amino acid source to supply energetic demands. Thus, well-suited diet composition is needed to prevent losses of amino acids as caloric substrate. High dietary protein levels are also associated to inconvenient environmental impacts due to potential nitrogenous waste resulting in water eutrophication. Protein requirement is also dependent upon the levels of other non-protein energy sources (Ruohonen and Kettunen, 2004). Besides, the content variation of macronutrients is essential to maintain the energetic equivalence based on their bio-availability.

The activities of glycolytic enzymes may fluctuate in response to the concentration and/or type of dietary carbohydrates. In Labeo rohita, the ratio between dietary non-gelatinized and gelatinized starch do not affect the glycolytic activity (Vikas et al., 2010). However, higher activities of glycolytic enzymes are observed in gilthead sea bream fed diets with gelatinized corn starch (Fernandez et al., 2007). Controversial results were posteriorly observed on the hepatic HK and PK activities (Enes et al., 2008. Notwithstanding, when the type of carbohydrate - glucose and maltose - is changed, an increase of GK and PK activities is observed in that species (Enes et al., 2010).

In this work, decrease of dietary carbohydrates lessened the activity of glycolytic enzymes. The highest levels of those enzymes were found in the fish fed with lower CP or highercarbohydrate diets. Consistently, the hepatic activity of the gluconeogenic enzyme FBP-1 was correlated with the dietary $\mathrm{CP}$ content $(\mathrm{PC}=$ $0.94 ; \mathrm{P}<0.05)$. Increased protein in the diets enhanced this enzymatic activity in the liver.

The pattern of glycolytic and gluconeogenic enzymes on grounds of dietary nutrients suggests catabolism of amino acids (Fig. 2). This pattern was followed by a shifting of the amino-acidscarbon-backbones toward glucose synthesis. This framework is in agreement with the previous assumption of gluconeogenesis following the CP increase. Similar results are observed in $S$. aurata and O. mykiss fed with high levels of protein (Caseras et al. 2002; Metón et al. 2003). The gluconeogenic pathway is widely reported in liver and also in other tissues (Tam et al., 1998). Gluconeogenesis is an important strategy to regulate the blood glucose concentration, even in fish. The balance of plasma glucose may reflect the gluconeogenic activity. Variations of the plasma glucose concentrations in fish, as also observed from results with glucose tolerance tests, emphasizes the role of adaptation to the diets and are interpreted in the context of secondary carbohydrate metabolism (Hemre et al., 2002).

The FBP-1 is a regulatory enzyme playing a key role in this process to gain glucose from nonsugar molecules. The gluconeogenic strategy proposed in the present dietary conditions is substantiated in the changes observed in such enzyme activity, also reported in other fishes (Panserat et al., 2000). Depending on the type and the amount of carbohydrate and protein in the fish diet, the gluconeogenesis can be induced. The use of no-gelatinized starch in the diet to $L$. rohita induces gluconeogenesis from amino acids metabolism (Kumar et al., 2010). In addition, the gluconeogenesis may occur due to the inability to utilize carbohydrates from the feeding (Enes et al., 2009).

Regarding the enzymatic activities of G6PDH and 6GPDH in the liver of catfish, the only response was obtained in fasted fish. The concentrations of protein, carbohydrates and lipids did not affect these enzymes. However, it must be considered that such enzymes may not be responsive to nutrients from food or fasting (Metón et al., 2003).

The couple of intersections in the family of the curves for the enzymes assayed in this work (Fig. 2a) are inserted into a range between treatments 2 and 3. The values for such range correspond to about $29 \%$ of CP, $37 \%$ of carbohydrate and 14 $\%$ of lipid (Fig. 2b). This set of macronutrient values does not match the performance measurements. One must consider that inferences from the performance data do not take into account several conditions such as waste of amino acids, excessive excretion of nitrogen, ability of using different nutrients, metabolic plasticity to diets, etc. On the other hand, it suggests the possibility of fine adjustments to 
achieve the best formulation on dietary macronutrient and fish performance subsequently. The optimal concentration of dietary protein is different among fishes and depends on the food habit (omnivorous or carnivorous). For example, the best weight gains are in pintado Pseudoplatystoma corruscans (Lundstedt et al., 2004), Mugil platanus (Carvalho et al., 2010), Sparus macrocephalus (Zhang et al., 2010). Concerning carbohydrates, the recommended amount to reach the best performance is also distinct among fishes. The optimal levels of carbohydrate for Puntius gonionotus (Habieb et al., 1994), Clarias batrachus (Mollah and Allam, 1990) and Mystus montanus (Raj et al., 2008) are 30, 15-20, 9.5 \%, respectively.

\section{CONCLUSION}

In conclusion, $R$. quelen is a freshwater fish species able to adapt the carbohydrate and amino acid metabolic pathways according to the dietary content of protein and carbohydrate. Such ability allows us to risk that $40 \%$ of CP, $24 \%$ of carbohydrate and $10 \%$ of lipid are good amounts of such nutrients to reach the best weight gain. Instead of using only the growth parameters to establish the best performance, the present work encourages the use of biochemical evaluations to adjust the content of macronutrient components in the diet and to prevent undesirable, physiological effects and achieve inaccurate results.

\section{ACKNOWLEDGMENTS}

The authors are grateful to the colleagues at the Adaptive Biochemistry Lab for their logistical support. This research was sponsored by FAPESP (Sao Paulo State Research Foundation), CAPES (Coordination for the Improvement of Higher Education Personnel, Brazil), CNPq (National Council for Scientific and Technological Development, Brazil), and the Ministério de Ciencia y Tecnologia, Spain.

\section{REFERENCES}

BARTRONS, R.; HUE, L.; SCHAFTINGEN, E.; HERS, H.G. Hormonal control of fructose 2,6bisphosphate concentration in isolated rat hepatocytes. Biochem. J., v.214, p.829-837, 1983.

BERGMEYER, H.U. Methods of enzymatic analysis. New York: Academic Press, 1984. p.322.
CARVALHO, C.V.A.; BIANCHINI, A.; TESSER, M.B.; SAMPAIO, L.A. The effect of protein levels on growth, postprandial excretion and tryptic activity of juvenile mullet (Mugil platanus) (Günther). Aquacult. Res., v.41, p.511-518, 2010.

CASTAÑO, J.; ANGEL NIETO; FELIU, J.E. Incactivation of phosphofrutoctokinase by glucagon in rat hepatocytes. J. Biol. Chem., v.265, p.5576-5579, 1979.

COWEY, C.B.; LAHIGUERA, M.; SDRON, J.W. The effect of dietary composition and of insulin ond gluconeogenesis in rainbow trout (Salmo gairdneri). Br. J. Nutr., v.38, p.385-395, 1977.

ENES, P.; PANSERAT, S.; KAUSHIK, S.; OLIVATELES, A. Hepatic glucokinase and glucose-6phosphatase responses to dietary glucose and starch in gilthead sea bream (Sparus aurata) juveniles reared at two temperatures. Comp. Biochem. Physiol. A, v.149, p.80-86, 2008.

ENES, P.; PANSERAT, S.; KAUSHIK, S.; OLIVATELES, A. Nutritional regulation of hepatic glucose metabolism in fish. Fish Physiol. Biochem., v.35, p.519-539, 2009.

ENES, P.; PERES, H.; COUTO, A.; OLIVA-TELES, A. Growth performance and metabolic utilization of diets including starch, dextrin, maltose or glucose as carbohydrate source by gilthead sea bream (Sparus aurata) juveniles. Fish Physiol. Biochem., v.36, p.903910, 2010

FERNANDEZ, F.; MIQUEL, A.G.; CÓRDOBA, M. et al. Effects of diets with distinct protein-tocarbohydrate ratios on nutrient digestibility, growth performance, body composition and liver intermediary enzyme activities in gilthead sea bream (Sparus aurata, L.) fingerlings. J. Exp. Mar. Biol. Ecol., v.343, p.1-10, 2007.

HABIB, M.A.B.; HASAN, M.R.; AKAND, A.M. Dietary carbohydrate utilization by silver barb (Puntius gonionotus). In: SILVA, S.S. (Ed.). Exotic Aquatic Organisms in Asia. Proceedings of the Workshop on Introduction of Exotic Aquatic Organisms in Asia. Asian Fish. Manila: Asian Fish Society, 1994. p.57-62. (Special Publication).

HEMRE, G.I.; MOMMSEN, T.P.; KROGDAHL, A. Carbohydrates in fish nutrition: effects on growth, glucose metabolism and hepatic enzymes. Aquacult. Nutr., v.8, p.175-194, 2002.

KUMA, S.; SAHU, N.P.; PAL, A.K. et al. Studies on digestibility and digestive enzyme activities in Labeo rohita (Hamilton) juveniles: effect of microbial amylase supplementation in non-gelatinized or gelatinized corn based diet at two protein level. Fish Physiol. Biochem., v.32, p.209-220, 2006. 
KUMAR, V.; SAHU, N.P.; PAL, A.K. et al. Modulation of key enzymes of glycolysis, gluconeogenesis, amino acid catabolism, and TCA cycle of the tropical freshwater fish Labeo rohita fed gelatinized and non-gelatinized starch diet. Fish Physiol. Biochem., v.3, p.491-499, 2010.

LUNDSTEDT, L.M.; MELO, J.F.B.; MORAES, G. Digestive enzymes and metabolic profile of Pseudoplatystoma corruscans (Teleostei: Siluriformes) in response to diet composition. Comp. Biochem. Physiol. B, v.137, p.331-339, 2004.

MACHADO, C.R.; GAROFALO, M.A.R.; ROSELINO, J.E.S. et al. Effects of starvation, refeeding, and insulin on energy-linked metabolic processes in catfish (Rhamdia hilarri) adapted to a carbohydrate-rich diet. Gen. Comp. Endocrinol., v.71, p.429-437, 1988.

MELO, J.F.B.; LUNDSTEDT, L.M.; METÓN, I. et al. Effects of dietary levels of protein on nitrogenous metabolism of Rhamdia quelen (Teleostei: Pimelodidae). Comp. Biochem. Physiol. A, v.145, p.181-187, 2006.

METÓN, I.; FERNÁNDEZ, F.; BAANANTE, I.V. Short and long-term effects of refeeding on key enzyme activities in glycolysis-gluconeogenesis in the liver of gilthead seabream (Sparus aurata). Aquaculture, v.225, p.99-107, 2003.

METÓN, I. Regulacion nutricional de enzimas clave en la glucolisis-gluconeogenesis: expresión del gen 6PF 2-K/FRU 2,6-P2ASA en hígado de Sparus aurata. 1996. (tesis doctorado) Universidad de BarcelonaFacultad de Farmàcia. 179p.

MOLLAH, M.F.A.; ALAM, M.S. Effects of different levels of dietary carbohydrate on growth and feed utilization of catfish (Clarias batrachus) L. fry. Indian J. Fish., v.37, p.243-249, 1990.

PANSERAT, S.; MÉDALE, F.; BRÈQUE, J. et al Lack of significant long-term effect of dietary carbohydrates on glucose-6-phosphatase expression in liver of rainbow trout (Oncorhynchus mykiss). J. Nutr. Biochem., v.11, p.22-29, 2000.
RAJ, A.J.A.; HANIFFA, M.A.; SEETHARAMAN, S.; APPELBAUM, S. Utilization of various dietary carbohydrate levels by the freshwater catfish (Mystus montanus) (Jerdon). Turk. J. Fish. Aquat. Sci., v.8, p.31-35, 2008.

RUOHONEN, K.; KETTUNEN, J. Effective experimental designs for optimizing fish feeds. Aquacult. Nutr., v.10, p.145-151, 2004.

SÁNCHEZ-MUROS，M.J.; GÁRCIA-REJÓN， L.; GÁRCIA-SALGUERO, L. et al. Long-term nutritional effects on the primary liver and kidney metabolism in rainbow trout. Adaptive response to starvation and a high-protein, carbohydrate-free diet on glutamate dehydrogenase and alanine aminotransferase kinetics. Biochem. Cell Biol., v.30, p.55-63, 1998.

SILFVERGRIP, A.M.C. A systematic revision of the neotropical catfish genus Rhamdia (Teleostei, Pimelodidae). 1996. 156f. Thesis (Doctoral in Zoology) - Department of Zoology, Stockholm University, Stockholm, SE.

STAAL, G.E.; KOSTER, J.F.; VEEGER, C. Human erythrocite pyruvate kinase. Methods Enzymol., v.42, p.182-186, 1975.

TAM, W.H.; FRYER, J.N.; ALI, I. et al. Growth inhibition, gluconeogenesis, and morphometric studies of the pituitary and interrenal cells of acid-stressed brook trout (Salvelinus fontinalis). Can. J. Fish. Aquat. Sci., v.45, p.1197-1211, 1998.

TRANULIS, O.; DREGNI, B.; CHRISTOPHERSEN, A. et al. Glucokinase-like enzyme in the liver of Atlantic salmon (Salmo salar). Comp. Biochem. Physiol. B, v.114, p.35-39, 1996.

VIKAS, K.; SAHU, N.P.; PAL, A.K. et al. Modulation of key enzymes of glycolysis, gluconeogenesis, amino acid catabolism, and TCA cycle of the tropical freshwater fish Labeo rohita fed gelatinized and non-gelatinized starch diet. Fish Physiol. and Biochem., v.36, p.491-499, 2010.

ZHANG, J.; ZHOU, F.; WANG, L. et al. Dietary protein requirement of juvenile black sea bream (Sparus macrocephalus). J. World Aquacult. Soc., v.41, p.151-164, 2010. 